\title{
SENTIMENT ANALYSIS OF PUBLIC ON SOCIAL MEDIA ON CSR ACTIVITIES BY FINANCIAL SECTOR COMPANIES DURING COVID-19 PANDEMIC
}

\author{
Udita Agrawal \\ Research Scholar, SHUATS- Sam Higginbottom University of Agriculture, Technology and \\ Sciences, Prayagraj, Uttar Pradesh, India

\section{Dr. Richa Sinha} \\ Assistant Professor, Sam Higginbottom University of Agriculture, Technology and Sciences, \\ Prayagraj, Uttar Pradesh, India
}

\begin{abstract}
In today's times of intense competition, survival depends on growth of business. However, the perspective of growth keeps on changing. In times like COVID-19 pandemic as is being faced today corporate social responsibility (CSR) becomes an important method for the businesses as they have responsibility towards society and people from whom they derive their success. Financial sector has also come forward with its CSR activities during these times and tried to gain public attention. In this paper, the sentiment analysis of the public on the social media towards the various CSR activities by such financial sector companies will be done qualitatively (using NVIVO) of people's comments on various social media forums. The analysis would help us understand that how such activities are viewed by the people in general.
\end{abstract}

Key words: pandemic, corporate social responsibility, qualitative analysis, sentiment analysis

Cite this Article: Udita Agrawal and Richa Sinha, Sentiment Analysis of Public on Social Media on CSR Activities by Financial Sector Companies during COVID-19 Pandemic, International Journal of Management, 11(12), 2020, pp 2882-2889.

http://iaeme.com/Home/issue/IJM?Volume=11\&Issue=12

\section{INTRODUCTION}

\subsection{Concept of CSR}

"Corporate Social Responsibility is a management concept whereby companies integrate social and environmental concerns in their business operations and interactions with their stakeholders. CSR is known as the way through which a company aspires to achieves a balance 
Sentiment Analysis of Public on Social Media on CSR Activities by Financial Sector Companies during COVID-19 Pandemic

of three requirements - economic, environmental and social which is also known as the "TripleBottom-Line- Approach", and at the same time it addresses the hopes of shareholders and stakeholders."

It is important to differentiate between CSR, which is a strategic business concept and charity or philanthropy as commonly it is called. Though charity or philanthropy is also making a valuable contribution to enhancing the reputation of the organization, the concept of CSR is much above that.

"Corporate Social Responsibility is a way of doing business that matches or exceeds ethical, legal, commercial and social expectations."

There are four areas where companies seek for benefits when CSR is considered. Firstly, and the most important is the business benefits for which organizations are working. This benefit is associated with more money, power, increased market share, brand value among others for business purpose.

Secondly, the individual or personal values are considered. The company wants to be perceived as a socially responsible organization and be seen in a better light. This is important as reputation of the company is very important for any business relationships.

Thirdly, CSR activities are done in compliance with industry's social expectations and standards, which helps organizations to be at par with others in the industry.

Last but definitely not the least, company's have to consider all the stakeholders of the organisation. It is important for the company to live up to their expectations. However, these expectations will be different for different stakeholders like, for employees' expectations would be sustainability, HR policies, reliability, appraisal system of the organization, among others. It is important for the organization to identify which benefit it wants by doing the CSR activity.

Companies have been practicing corporate social responsibility to contribute to the society they are dependent on and they affect. But sometimes CSR is seen as a business process expecting that each initiative undertaken under this deliver profits making companies deviate from the main purpose of CSR which is to align company's social and environmental activities with its business purpose and values. Many of these CSR activities reduce risks, boost status, and contribute to business results at the same time for many organizations the outcome of CSR activities is just additional over and above the benefits due to normal business activities.

\subsection{CSR in India}

Corporate Social responsibility (CSR), with the continuous changes in the global scenario, is all about integrating concerns about the society, environment and others into the strategic decision making of the organization and it has led the organizations to look beyond the financial purview of the organization.

Before the Companies Act 2013 came into force, CSR was not compulsory in India, rather seen as an activity done only for charity. And to keep pace with the traditional values of the country, it is expected that companies have certain obligations towards the society in which it is operating, which depends mostly on the financial position of the company. Mahatma Gandhi brought about the concept of trusteeship in early 90's with the sole objective of increasing the socio-economic strength of the country. CSR was more inclined towards traditional family values, norms, religion, culture among others.

The Companies Act 2013 replaced the Companies Act of 1956 on 29th August 2013. The new Act incorporated various changes that had an affect on the formation of the company, its administration, and governance, along with the incorporation of an additional Section 135 which is on Corporate Social Responsibility norms for companies listed in India. This section 
covered the aspects related to requirements for execution, allocation of funds and implementation of CSR project by the organizations.

Following the amendment of the Companies Act 2013, India was the first country in the world to make CSR mandatory for organizations, to undertake CSR activities and report the CSR initiatives. This was altogether a new beginning for CSR in India.

A brief description about Section 135 of the Companies Act, 2013 describing the provisions and areas covered under CSR:

"To know about the entities covered under the CSR Obligations - Companies having an annual turnover of Rs.1,000 crore or more or a net worth of Rs.500 crore or more or a net profit of Rs.5 crore or more have to form a CSR Committee consisting of three directors where one director should be independent. An unlisted public company or a private company covered under Section 135(1) of the Act, is not required to appoint an independent director, and can have its CSR Committee without such director whereas a private company with two directors on Board should form CSR Committee with only two directors. The monitoring of the various projects or activities or programs undertaken by the company should be transparent. The companies which fulfil the required criteria, as part of CSR expenditure have to spend a minimum $2 \%$ of its average net profit for its preceding three financial years amount and reporting of these activities should be detailed in Schedule VII, else should be prepared to explain why they failed to do so."

\subsection{CSR by Financial Sector Organizations}

There has been slow development of CSR in India. But after gaining momentum CSR has assumed greater importance not only in the corporate world but also in the financial sector. Recently, there has been a lot of advancement in the CSR activities of financial sector by using environment friendly products and financial practices which are socially responsible. The Government of India is pursuing the matter relating to CSR and also drafted guidelines for CSR practices time to time.

Financial sector like banks are high involvement services as they are crucially important to the customers and are risky too, and have long term relationship with the customers once they are acquired.

Over the recent years, even financial sector companies' life banks, mutual funds, NBFC's have started increasing their spending on CSR as customers have become more aware and bringing the CSR orientation into strategic level helps organizations to gain competitive advantage. CSR activities in financial sector are in the various areas of education, environment, society, health, customer satisfaction and employee wellbeing. In case of financial sector, there is great variations in the consumers reaction to CSR initiatives like consumers may or may not reward the organization based on the CSR activity, or they may not perceive the CSR activities in good light, etc.

\subsection{Policy change in CSR due to Covid-19 pandemic}

Coronavirus disease, more commonly known as COVID-19 caused by a newly discovered virus named coronavirus had been an infectious disease which gradually led on to become a pandemic affecting not only India but worldwide. The best way to control the disease had been to prevent and slow down the transmission and protecting oneself by wearing masks all the time.

This contagious disease drastically affected the socio-economic situation of the whole world.

There was a lot of steps taken up by companies as part of CSR projects. This was mainly due to the three changes that were made in the policy which showed a drastic increase in the 
degree of CSR spending. Though one could not see anything positive during the time of pandemic, however there had been one positive development during this time. It has made organisations more conscious with respect to their responsibility to the society in which they are operating.

Also, the money that was being spent on CSR was more in line with sustainable development and other areas of national interest, along with many times money also directly going to government on various projects.

The first change in policy was to allow companies spending on Covid-related activities could be done from CSR funds. Any contribution done to the PM CARES Fund or the State Disaster Management Authority, along with any expenditure on preventive healthcare, sanitation, payments done to temporary/casual workers beyond daily wages, amongst others, could be considered as CSR spend.

The second change in policy and most important was to allow all spending on Covid-related activities to be eligible for 100 per cent tax deduction.

And last but not the least, third change was to allow companies who have made contributions over and above the minimum prescribed amount can later offset the excess funds against the CSR obligation in coming subsequent years, if desired.

\subsection{CSR by Financial Sector Organizations during Covid-19}

Along with the change in CSR policy during the pandemic, Government of India is also encouraging companies to provide support for the society in whatever way is possible for them.

Financial sector organizations are basically involved in boosting the economic growth of the country and though all sectors faced a complete lockdown during Covid-19, financial sector organizations like banks, NBFC's etc have been continuously working for the betterment of the society. Financial sector companies, especially banks never gave much importance to CSR funding. But recently, banks and other financial sector organisations have started spending in CSR activities and have started looking beyond their core business and contributing in projects and programmes for the environment, welfare of the society and others.

The CSR activities not only improves the performance of financial sector organizations in goodwill, social image and expanding business but it also sets example for other industries to contribute to the society.

During the pandemic, all the industries came forward to contribute to the society. The change in CSR policy was one of the major reasons for increase in CSR during the pandemic. However, companies also contributed as consumers were also keeping a keen eye on the contributions made by the companies and in which area.

Most of the contributions were made to PM Cares Fund or State relief fund to help the government to handle the pandemic situation. Contributions were also made to various hospitals, in terms of donating various ventilators, medical equipment, PPE kits, and other sanitization facilities. Some went ahead providing quarantine facilities to the government for the people.

CSR programs give maximum benefit to the organizations done at a time when it is most required. This fact has been proven by the donations and contributions by corporates in the time of the pandemic. 


\subsection{Social Media}

Social media has many definitions each different from different perspectives like that of the user, content, business or technological perspective. There are three aspects of social media content, technological and sociological.

Based on technological aspect, social media is defined as "a group of internet-based applications that build on the ideological and technological foundations of Web 2.0, and allow the creation and exchange of user-generated content." If we break the word social media into two - "Social is described as a group of people with relations between them while media can be described as an instrument with the purpose to provide communication." When the two words are combined, 'social media' becomes a medium for people to communicate online amongst themselves.

Social media affects the lives of people, personally and professionally in both good and bad ways.

Disadvantages of Social Media: Reliability and trust are the most important issues with social media related to the information provided. Social media posts are easy to create and lot of incorrect information can be there. People also become addicted to social media which affects their personal life. Threat of computer security and privacy issues are also critical concern of social media.

Positive Aspects of Social Media: The social media allows users to share their content, express their feelings and views on any topic of their interest. The biggest advantage of social media is that people can stay in touch with friends, families and also other users can also get connected and make new friends online. With the help of social media, new skills can be learned and acquired, new content can be created and managed, a wider audience can be reached, and can be useful for education purposes. Nowadays, social media has become an important and powerful tool for business purposes, like promoting the products, selling and buying online, interacting with customers and giving effective customer service and in promoting it online.

\section{REVIEW OF LITERATURE}

Narwal (2007) studied the corporate social responsibility (CSR) initiatives which taken by the Indian Banking Industry so as to enhance their overall performance. The study was conducted on 33 banks which have undertaken CSR activities under the supervision of their head office . The findings clearly show that banks concentrated their CSR activities on education, environmental marketing, balanced growth in different strata of society, health and customer satisfaction. The Indian banking industry adopts a cohesive approach and combines CSR with customer satisfaction.

Singh \& Gautam (2010) explored the various aspects of Corporate Social Responsibility (CSR), history of CSR like its development over the years in India and the current practices of CSR in the country. The paper examined the view of India's top 500 companies with respect to key CSR practices conducted by them and mapped those against Global Reporting Initiative standards.

Chen (2011) presented a method for identification of a model for corporate CSR with best goodness-of-fit. The research helped the researcher to create a model where CSR was affected by four main components: accountability, transparency, competitiveness, and responsibility. The researcher applied structural equation modelling to assess the proposed CSR model which contained four latent factors and 13 observation indicators. Confirmatory factor analysis done on the data indicated that there was significant correlation among the four latent variables, and the second-order factor structure fit the observed data well. 
Pavlíček and Petr Doucek (2015) in their paper describes how companies are using social media platforms like Facebook and Twitter to accomplish their goal of CSR communication. Ten global companies were taken as the sample who had the best reputation for CSR and their social media activity was tracked down, along with the content posted by their customers like any post, like or comments. It was seen that companies taken on an average dedicated about 10 percent of communication on social media to CSR, mainly on Facebook. However, CSR issues are not of much interest to the readers but there has been mostly positive user sentiment related to CSR messages. CSR is well established on social media channel and is being extensively used by companies for communication.

Koli \& Mehta (2020) in their paper examined how various CSR activities taken up by the companies are not applicable from the point of view of ethics, legality and business responsibility. These activities do not necessarily violate the rules of law, but one should look at the essence with which these activities are taken up.

Stanislavská, et al (2020) in their study found how different is the perception of the term 'CSR' on social media platform Instagram between developing and developed countries. They analysed Instagram messages from users worldwide. There are some common features in developed and developing countries such as philanthropy and social well-being whereas a difference is seen in some areas of sustainability, which is important in developed countries, and the area of education, which is important in developing countries. Community analysis was done to find out dominant communities in both developed and developing countries. The results helped to manage CSR strategically so that the communication can be adapted to local environments and company contexts. The findings of the research allowed managers to focus CSR activities on the issues that are more relevant in developing countries and subsequently they could differentiate CSR communication from organizations competing with each other.

Vethirajan, C. et. al (2020) in their study identified leading industries which were involved in CSR practices in the pandemic period. CSR activities taken by corporates during the covid19 epidemic created good image, reputation and name among their customers.

\section{RESEARCH METHODOLOGY}

The data is collected through social media platform Twitter where opinion of the public is captured and downloaded easily. New project is created for each of the data collected and the data is analysed qualitatively using NVIVO.

"NVivo is a software program which is used for qualitative research and other mixedmethods research. It is used for the analysing unstructured data like text, audio, video, and images, including data containing interviews, focus groups, surveys, social media content, and journal articles. The software is produced by QSR International."

It is used to analyse and organize unstructured data like text, audio, video, or images. It has playback options for audio and video files to record interviews. Also, data from various social media platforms can be captured using the NCapture plug-in option in browser. It is also possible to import notes and captures, citations from various sources which can be used further. The various language options available are English, French, German, Spanish, Portuguese, Japanese, and Simplified Chinese.

\section{DATA ANALYSIS AND INTERPRETATION}

The tweets were downloaded using various hashtags \#CSR \#India \#banks \#insurance \#mutualfunds among others for the period January 1, 2020 to December 31, 2020 to get the data of all the tweets during the pandemic period. 
The tweets are downloaded as dataset using NCapture plugin and it is imported to NVivo where it is auto-coded for doing the sentiment analysis.

The sentiment analysis can be done based on words, full sentences or full paragraphs in NVivo.

However, the tweets downloaded for this study were not huge showing that there is huge lack of awareness among people in India regarding CSR.

Sentiment analysis is done on criteria very negative, moderately negative, neutral, moderately positive and very positive. The tweets downloaded are auto-coded to do the sentiment analysis of the public on the posts on Twitter.

Most of the results obtained through sentiment analysis were mainly moderately positive and very positive along with few also of moderately negative. The analysis done on moderately negative found that customers were mainly suspicious of the CSR activities taken up by finance companies were not genuine. The detailed analysis of the words used in the opinions showed that those people did not had the complete idea of the concept of CSR and why these activities are taken up.

The detailed analysis of moderately positive and very positive responses showed that people had positive opinion about the activities taken up by the companies which enhances the brand value and showed that particular financial sector company like banks, mutual funds, NBFC's, etc, government or private both, are responsible towards the society apart from dealing with financial situations of the country.

To have more detailed study on CSR and study the sentiment analysis of CSR, tweets were captured with hashtag \#CSR which captured tweets from all over the word ranging to around 6700. When analysed further and this data was studied area-wise it was found that only 170 tweets were from India (around 2.5\%) which further proves lack of awareness in the country regarding CSR.

\section{CONCLUSION}

It can finally be concluded that a lot has to be done to increase the awareness of the public regarding the concept of CSR and the activities taken up by the various organizations. Not only financial sector but companies in all the sectors can benefit a lot in terms of goodwill among customers and enhancement of the social image in the eyes of the customers leading to increase in brand value and more loyal customers. The customers realize that the companies doing CSR activities are more responsible towards the society in which they are operating. Also, in case of financial sector organizations, the customers positive opinion about the CSR activities makes those organizations more attractive to the customers to do business with those organizations and invest more in those companies as those companies would be seen as more socially responsible and genuine with respect to their efforts in being more socially responsible by engaging in CSR activities.

\section{REFERENCES}

[1] Narwal, M. (2007), 'CSR Initiatives of Indian Banking Industry', Social Responsibility Journal, Volume 3, No. 4

[2] Gautam, R \& Singh, A (2010), 'Corporate Social Responsibility Practices in India: A Study of Top 500 Companies', Global Business and Management Research: An International Journal, Vol. 2, No. 1, pp. 41-56 
Sentiment Analysis of Public on Social Media on CSR Activities by Financial Sector Companies during COVID-19 Pandemic

[3] Chen, C.H. (2011), 'The major components of corporate social responsibility', Journal of Global Responsibility, Vol. 2, No. 1, pp 85-99

[4] Pavlíček, A. and Doucek, P. (2015), 'Corporate social responsibility in Social Media Environment', IFIP International Federation for Information Processing, pp 323-332

[5] Stanislavská, et al (2020), 'Corporate social responsibility and Social Media: Comparison between Developing and Developed Countries', Sustainability, Vol. 12, pp 5255

[6] Vethirajan, C. et al (2020), 'Corporate Social Responsibility Practices by Indian Industries during Covid-19', JAC: A Journal of Composition Theory, Vol. 13, No. 5, pp 67-77

[7] Koli, A. and Mehta, R. (2020, December 10). Corporate social responsibility practices in the times of COVID-19: A study of India's BFSI sector. Retrieved on January 11, 2021, from the DownToEarth:

[8] https://www.downtoearth.org.in/blog/governance/corporate-social-responsibility-practices-inthe-times-of-covid-19-a-study-of-india-s-bfsi-sector-74583

[9] Parekh, N.J. (2020, June 07). CSR in times of COVID-19. Retrieved on January 13, 2021, from the Financial Express: https://www.financialexpress.com/brandwagon/csr-in-times-of-covid$19 / 1983907 /$

[10] Choudhary, S. et al. (2020, September 03). The Changing Landscape of CSR in India during COVID-19, Invest India. Retrieved January 14, 2021 from Strategic Investment Research Unit (SIRU):_https://www.investindia.gov.in/siru/changing-landscape-csr-india-during-covid-19

[11] Das, S.K. and Ray, N. (2020, May 16). Corporate social responsibility in times of Covid-19 Pandemic. Retrieved January 14, 2021 from ET Government:

https://government.economictimes.indiatimes.com/news/economy/corporate-socialresponsibility-in-times-of-covid-19-pandemic/75771467 